\title{
Lib-Value: Values, Outcomes, and Return on Investment of Academic Libraries, Phase III: ROI of the Syracuse University Library
}

\section{Bruce Kingma and Kathleen McClure}

This study measures the return on investment (ROI) of the Syracuse University library. Faculty and students at Syracuse University were surveyed using contingent valuation methodology to measure their willingness to pay in time and money for the services of the academic library. Their travel time and use of the online library was measured to determine the environmental value of the academic library. The economic and environmental value of the Syracuse University library show an ROI of $\$ 4.49$ returned to the university for every $\$ 1.00$ spent each year.

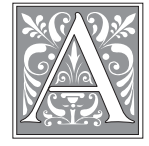

cademic libraries have budgets ranging in the millions of dollars, but does the value gained from them justify the expenditure? Furthermore, which areas of library service provide the most value per dollar spent? The Syracuse ROI study is one step in the ongoing efforts to calculate the value of the academic library to its institution, constituents, and environment. The study also points to areas of greatest value return and possible improvements to library services.

In the fall of 2010 and spring of 2011, faculty and students at Syracuse University were surveyed regarding their usage of the library resources and services. Their responses and demographic statistics were used to calculate the Syracuse University Return on Investment (SU-ROI). This study used contingent valuation (CV), a surveybased technique used in economics to determine the value of goods and services not directly sold to consumers.

\section{Background}

In 2006, recognizing the need for evidence of the value of the academic library, the University of Illinois at Urbana-Champaign (UIUC), in partnership with Elsevier, conducted an ROI study that became the foundation (now referred to as Phase I) for the Lib-Value project. This study employed a formula using the library's budget, faculty grant income, and faculty surveys and found that for every dollar invested in the library, there was a return of $\$ 4.38$ in grant income.

Bruce Kingma is a Professor in the School of Information Studies and Whitman School of Management at Syracuse University; e-mail: brkingma@syr.edu. Kathleen McClure is Systems Librarian at the Okefenokee Regional Library System, e-mail: kmcclure@okrls.org. (c) 2015 Bruce Kingma and Kathleen McClure, Attribution-NonCommercial (http://creativecommons.org/licenses/by-nc/3.0/) CC BY-NC. 
The study was expanded in 2008 to Phase II, which applied the methodology to eight institutions in eight countries. Qualitative as well as quantitative data were collected, including institutional demographic figures, faculty surveys, and interviews with administrators. In six of the eight institutions, ROI for grants was found to be higher than 1:1.

The study then expanded again in 2009 into a three-year project funded by the Institute of Museum and Library Services (IMLS) known as Values, Outcomes, and Return on Investment of Academic Libraries or Phase III of the Lib-Value project. The research centered on institutional outcome areas of teaching/learning, research, and the social, professional, and public engagement functions of the library. Syracuse University was one of three institutions to initially participate in this phase of the Lib-Value project.

This paper adds to the base of empirical research about academic library value, library contribution to institutional outcomes, and assessment using the Lib-Value CV method. While valuation studies exist, there is a shortage of publications that empirically test for the return on investment or measure the benefit of an academic library. There are a considerable number of ROI studies on public libraries, but SU-ROI is the first on the holistic value of an academic library. SU-ROI contributes to the breadth of data on library assessment and the CV method.

The Lib-Value project is continuously evolving and being expanded upon. Since 2009, Drexel University, Bryant University, Baruch College, Brooklyn College and Buffalo State University have joined the project and implemented surveys.

\section{Literature Review}

Libraries feel increasing pressure to demonstrate value to their communities. These institutions face greater competition, rising costs, lower budgets, and greater pressure to demonstrate their success. The value demonstrated by an ROI study can be leveraged within the institution to advocate for the library budget. It can also reveal the relative effectiveness of library services' contributions toward institutional outcomes, determining which should be prioritized or improved.

The methods, consistency, and perspective of library assessment have all changed greatly over the past few decades. Library assessment began with the nonuniform collection of input-output statistics upon which limited or no analysis was done. ${ }^{1}$ In the late '80s and '90s, service quality and user satisfaction research emerged, dominated by SERVQUAL and the GAP method. SERVQUAL is a framework that measures aspects of service quality and identifies "gaps" that hinder the delivery of high-quality service. SERVQUAL pinpoints gaps caused by being unaware of consumers' expectations, by having the wrong service quality standards, by service delivery failing to meet standards, by ineffective communication of services, and by services failing to meet customer expectations. ${ }^{2}$ SERVQUAL and service quality assessment continues in popularity today through LibQUAL+ ${ }^{\mathrm{TM}}$, a widely used library assessment tool. ${ }^{3}$

With the rise of service quality and user satisfaction research, libraries began to employ surveys, focus groups, interviews, and complaint analyses with greater frequency. This shifted assessment from the tangible to the intangible. The consistency of assessment shifted from the piecemeal collection of data to systematic collection and analysis. The perspective of assessment shifted from service providers to users. ${ }^{4}$

Recently, perspective has shifted again as outcome-oriented assessment has boomed in popularity. ${ }^{5}$ Outcome-oriented assessment methods determine the relative success or failure of library services in relation to specific institutional outcomes such as learning achievement, grades, persistence, graduation rates, and job placement. ${ }^{6}$ Outcomes related to faculty include publication output, grant income, conference contributions, national and international awards and recognition, citation impact, and patents. ${ }^{7}$ 
Outcome-oriented assessment methods investigate the relationship between institutional goals such as student success and factors such as student engagement with the library $^{8}$ and information resource instruction. ${ }^{9}$

The Ithaka Faculty Survey, begun in 2000 and conducted every three years, is one of the most comprehensive examinations of faculty perceptions and practices available. The Ithaka survey uses faculty perceptions to determine library contributions to institutional outcomes and how libraries can improve services for faculty. In 2009, the Ithaka survey identified a shift in libraries' role from gateway, buyer, and archive to a support service hub for research, teaching, learning, and collaboration. ${ }^{10}$ In 2012, the survey found a slight resurgence of value for library-as-gateway and an increase in the number of respondents who want to see significant changes made to the library. ${ }^{11}$

Most recently, ROI studies have emerged from outcome-oriented assessment, in conjunction with influence from the field of economics. ${ }^{12}$ ROI studies for the library look at how the library contributes to revenue-generating activities and creates value for students and faculty.

Many economic studies of the ROI of public libraries and of environmental goods use contingent valuation (CV) to provide an estimate of the value of their services when users receive those services for free. ${ }^{13} \mathrm{CV}$ surveys ask patrons what they would be willing to spend in time and money to get access elsewhere to the information resources they recently received from the library. This method allows researchers to calculate the average patron-assessed value of access.

The field of economics has used CV since the 1940s to estimate the value of environmental resources. One criticism of $\mathrm{CV}$ is the overvaluation of public goods due to survey respondents giving answers greater than their true willingness to pay for a good or service. ${ }^{14}$ As with other survey methods that rely on self-reporting, lack of high stakes for students responding creates a problem of motivation to answer seriously and accurately. ${ }^{15}$ However, over the years, CV survey questions have often been adapted to account for this possibility. ${ }^{16}$ Further investigation of studies using selfreported data suggest that aggregated results accurately reflect value. ${ }^{17}$ An excellent review and critique of this literature can be found in The Journal of Economic Perspectives in 1994, while the 1989 Mitchell and Carson book on CV remains the standard for implementing a survey. ${ }^{18}$

While there have been a number of studies attempting to assess or quantify the value of libraries or to assess academic productivity, few have looked at correlation between student and faculty research productivity and library resources and services before the 2006 Lib-Value Phase I foundational study at UIUC. The UIUC study adapted the Willingness-To-Pay approach employed by Roger Strouse in 2007 in "ROI for Libraries Remains High." In it, Strouse measures the value of a corporate library to the organization's revenue-generating activities. ${ }^{19}$ The UIUC study modified this method for academic libraries by measuring their contribution to faculty grant income. ${ }^{20}$

The UIUC study looked at the library budget, faculty grant income, and faculty surveys and found that, for every dollar spent in library funding, the university received $\$ 4.38$ in research grant income. ${ }^{21}$ The UIUC study established a methodology to determine one way in which the library contributes to a university. To get a fuller picture of the impact of library services, Phase II included surveys and interviews about the goals and outcomes of faculty and administration and ways in which the library contributed to those outcomes.

Like Phase I, Phase II of the Lib-Value project looked at the amount of successful grant funding obtained when grant proposals included citations acquired from library collections. ${ }^{22}$ In addition, faculty members were surveyed on the value of library e-resources, and university administrators were interviewed about their institutional goals. The 
surveys and interviews helped provide a fuller picture of the library's role in aiding institutional goals. These goals included attracting and retaining productive faculty, fostering research, facilitating collaboration, and increasing the university's prestige. ${ }^{23}$

Phase II found that every dollar invested in academic libraries resulted in a ROI ranging from 15.54:1 to $0.64: 1$ in research grant income. For e-collections alone, this rate jumped to between 155:1 and 6.4:1, ten times that of the entire collection taken as a whole. ${ }^{24}$ There was a wide range of results obtained from the different universities, which was likely the result of differences in institutional goals and academic focus areas. For example, schools focused on science, technology, and medicine are more likely to attract grants, since there are more grants available in these areas versus the social sciences. In survey responses, faculty members said access to library resources allowed them to work more efficiently, improve research and teaching, and prepare grant proposals more easily. ${ }^{25}$

Phase III of the Lib-Value project further expands upon the methodology by looking at the social and professional activities of faculty as well as research and the satisfaction of faculty and students with the library. SU-ROI is part of Phase III of the Lib-Value project. The focus of SU-ROI is to provide a holistic measurement of the value of the academic library.

In addition to its Lib-Value predecessors, SU-ROI investigated research methodologies used for academic, public, school, and special libraries, recognizing that each type of library works within a larger context where it must answer to its institution and demonstrate its value. The approaches used and lessons learned from each of these libraries provides valuable guidance for college and university libraries. Information was gathered from published literature, conference proceedings, and prepublished materials from ACRL members. ${ }^{26}$ This information included a wealth of input-output analysis, satisfaction measures, and service quality analysis; however, there was a scarcity of information on the contribution of libraries to the achievement of outcomes within an institutional context. ${ }^{27}$ Unlike previous studies on academic libraries, SU-ROI uses a formal application of the contingent valuation method to measure the value for the entire academic library to its patrons.

Megan Oakleaf's The Value of Academic Libraries: A Comprehensive Research Review and Report is intended to provide a valuation framework for professional librarians. In it, Oakleaf makes an extensive review of methodologies and best practices in the area of ROI in libraries. The Value of Academic Libraries report provides a number of "next steps" to be taken in ongoing research. These include defining outcomes aligned with the mission of the overarching institution beforehand, showing the connection between library resources and services, and improved student learning, performance, retention, and graduation rates, and linking the library to facilitation and improvement of faculty performance in teaching, research, and professional service. ${ }^{28}$ Oakleaf recognizes the differences that exist between institutions and the guidelines provided by the study reflect that diversity. It depends on institutional culture whether quantitative or qualitative data should be emphasized in the method used. SU-ROI used quantitative methods to demonstrate value.

A key point in The Value of Academic Libraries is that "all assessment methods have advantages and disadvantages," and "no tools are perfectly valid or reliable." ${ }^{29}$ To address this, Oakleaf and others recommend multiple method approaches. ${ }^{30}$ Phase III and SU-ROI respond by including population and usage data as well as quantitative and qualitative survey responses.

Twenty years ago, the Special Libraries Association commissioned a similar comprehensive report, Special Libraries: Increasing the Information Edge, identifying two important roles of organization libraries: providing information and facilitating com- 
munication. ${ }^{31}$ Professionals reported substantial savings relative to the cost of acquiring and using information, resulting in a ROI of about 10.2 to 1 . Library users were willing to pay $\$ 8.50$ for library-provided information for every dollar spent in library operating cost. ${ }^{32}$ Libraries also helped reduce communication time and ensured that time devoted to communication was spent efficiently and effectively.

A 2007 report by Susan Imholz and Jennifer Arns called Worth Their Weight: An Assessment of the Evolving Field of Library Evaluation similarly surveyed 17 public library valuation and impact studies conducted between 1998 and 2006. ${ }^{33}$ The methods used in the impact studies included cost-benefit analysis, economic impact, and social return on investment.

One key finding of the Worth Their Weight report is that public library researchers have had increasing success over the past decade in adopting the methods and language of the economics field to quantify the value of library programs and services and to express that value in cost-benefit terms. ${ }^{34}$ Another key finding is that methodologies relying only on economic measures are diminishing in favor of those incorporating social return on investment (SROI) and the social dividends and cultural benefits of the public library.

The Worth Their Weight report found a number of barriers to the future potential of economic impact research, including the absence of a coordinating organization that can steer advocacy and research issues, the fact that there is no national research agenda or data standards, and the lack of a common informational collaboration forum. ${ }^{35}$ The Worth Their Weight report recommends the formation of a collaboratory, "a web-based environment that includes forums for sharing information, multiple datasets, and open-source experimental tools." ${ }^{36}$ This collaboratory would support the growth and development of the field of library economic valuation.

While Phase III and the SU-ROI study fall short of forming a collaboratory, it provides another example using the contingent valuation methodology and therefore broadens the data available and collective experience of library valuation studies.

\section{Methodology}

Syracuse University is a private institution in upstate New York with 21,029 students and 1,013 faculty members. The university has 11 schools and colleges including nationally ranked programs in library science, public communications, public administration, architecture, and entrepreneurship. The university libraries employ 184 fulltime equivalent staff and include Bird Library, which has a central location on campus, the Carnegie Library, which serves the sciences, and the Law Library. Together, these libraries attract over one million visits a year.

The survey method used in Phase I of the Lib-Value project was modified and employed at Syracuse. Contingent valuation studies rely on user-reported data and often employ surveys to obtain those data. In 1986, Martin Cummings, former director of the National Library of Medicine, said, "The best assessment of benefits incorporates the judgments of library users, whose levels of satisfaction vary widely." ${ }^{37}$ The purpose of the survey and the questions asked was to attempt to determine the value of the library and its various services to users. SU-ROI uses both usage statistics and user survey responses to determine the value of the library.

For this study, faculty and students were surveyed during peak months of library use during the semester to ensure a high response rate based on valued use. Faculty members were surveyed during October of 2010. A random sample of 222 faculty members was surveyed online, receiving 91 responses (41 percent response rate, 9 percent of the total faculty). Students were surveyed during March of 2011. A set of faculty from every school and college teaching graduate and undergraduate students 
was asked about distributing a survey in their classes. All faculty members who were asked agreed to distribute the survey. Courses required for student academic programs were chosen to ensure a significant number and diversity of students. It was explained beforehand that the survey was voluntary and would in no way affect students' grades. A graduate student distributed the surveys at the beginning of the class period, giving students 20 minutes to complete the surveys. Surveys were distributed in 26 classrooms to 841 students and also disseminated online, receiving 782 responses $(93 \%$ response rate, $4 \%$ of the total student body).

Faculty and students at Syracuse University were asked to recall their most recent visit remotely and in person to the academic library. The survey consisted of openended questions where students and faculty were asked to fill in the number of visits or number of minutes spent using various library services and the number of resources (books, article, and so forth) used. They were asked what they would be willing to pay in time and money to acquire the service from another location if it had not been made available by the library. From these responses, the average value of the various library services was calculated. Faculty and students were also asked to recall the number of times they used the library in the past 30 days, remotely and in person. The answers to this question give a self-reported estimate of the use of various library services.

To get the total use of services of the academic library, we multiplied the monthly use of services times the number of months times the total number of students or faculty. The use-per-month was weighted by the average in-person or online use of the library taken from turnstile and web-log statistics.

The survey finished with demographic questions. For students, this included gender, department, year in school, and approximate grade point average. For faculty, the questions included gender, department, rank, number of publications and grants awarded, and percentage of time spent in research, teaching, and service. Survey results were statistically adjusted by gender and academic discipline to reflect these percentages at Syracuse University.

\section{The Economics of University Libraries}

The methodology of the Syracuse ROI study is based on a number of assumptions taken from the field of economics. ${ }^{38}$ Economists define private goods as goods that provide value to an individual consumer. A university education is a private good. A student pays tuition for the value of the education, which, upon completion of their degree, will increase the student's salary or quality of life. The expected value the student will receive from the education exceeds the amount of tuition the student pays. Private goods provide benefit to the consumer and profit to the producer.

Public goods provide value to many consumers. The academic library provides access to information and services to several users simultaneously. When the library purchases a subscription to an online journal, many library patrons can access the journal articles without diminishing or subtracting from them. Public goods typically must be provided by an organization such as a government. Public goods are not "sold" to individuals, since preventing access can be costly and inefficient, and providing open access and relying on donations to pay for the goods results in an underprovision of the service. ${ }^{39}$

The library must determine which public goods to provide based on the total value to the patrons. Likewise, the university administration must determine how much funding to invest in the library based on the value of the public goods it provides. The ROI of the academic library is the total value of these goods to the patrons divided by the cost.

The value of a public good includes the economic, environmental, and social value. The economic value is the worth of access to the library resources by a patron. It is what a patron would be willing to pay for the services if he or she were required to 
purchase them. Patrons do not purchase access, but they can express what they would have spent in time and money if these resources were not available to them.

\begin{tabular}{|c|c|}
\multicolumn{1}{c|}{$\begin{array}{c}\text { FIGURE 1 } \\
\text { Library Value }\end{array}$} \\
\hline $\begin{array}{l}\text { Economic } \\
\text { - the value to a user/patron of use }\end{array}$ \\
$\begin{array}{l}\text { Environmental } \\
\text { - the energy savings from online access to } \\
\text { electronic resources }\end{array}$ \\
Social \\
- the prestige of having a great library
\end{tabular}

The environmental value of the library includes the resources saved by a library's provision of resources. Libraries have gone green by providing remote access, enabling patrons to save time and money by using online resources from their homes or offices. Patrons do not have to drive to the library and do not have to photocopy articles provided to them electronically.

The social value of the academic library is a more difficult concept to understand and to measure. The social value is the worth to everyone at the institution of having a great library. Likewise, there is social value at an institution of having great academic programs, top research faculty, and a great football team. A well-resourced library attracts new students, top researchers, and provides a community with pride for their university or college.

\section{Results}

Table 1 shows faculty and student demographics and productivity for survey respondents. Response bias by gender and academic program required weighting responses in subsequent tables to more accurately reflect the Syracuse University population. Note differing collection methods (in-class vs. online), which may have affected response rates for faculty and students.

Table 2 provides information on library use by faculty and students over the previous 30 days. It was found that faculty and students visit the library extensively in person and remotely. A total of 73 percent of faculty and 69 percent of students indicated that they visited the library in-person in the past 30 days, while 88 percent of faculty and 63 percent of students indicated that they had visited the library remotely. The average number of visits in a month range from 2.5 physical visits and 12.31 remote visits for faculty to 5.07 physical visits and 4.64 remote visits for students.

There is significant use of library resources - articles and books retrieved and read, government documents, special collections, library commons, and working with a professional librarian - by both faculty and students. It was found that students use the library commons area more frequently than faculty, while faculty members express a higher use of journal articles and books. 


\begin{tabular}{|c|c|c|}
\hline \multicolumn{3}{|c|}{$\begin{array}{c}\text { TABLE } 1 \\
\text { Demographics (Un-weighted) }\end{array}$} \\
\hline & Faculty & Students \\
\hline Category & $\%$ of Respondents & $\%$ of Respondents \\
\hline Survey Response Rate & $41 \%$ & $93 \%$ \\
\hline \multicolumn{3}{|l|}{ Status } \\
\hline Professor & $30.4 \%$ & \\
\hline Associate Professor & $33.0 \%$ & \\
\hline Assistant Professor & $29.5 \%$ & \\
\hline Professor of Practice & $1.8 \%$ & \\
\hline Instructor & $3.6 \%$ & \\
\hline Teaching Assistant/Fellow & $0.0 \%$ & \\
\hline Research Faculty & $1.8 \%$ & \\
\hline Freshman & & $17 \%$ \\
\hline Sophomore & & $25 \%$ \\
\hline Junior & & $10 \%$ \\
\hline Senior or 5th-year undergraduate & & $12 \%$ \\
\hline Graduate & & $31 \%$ \\
\hline \multicolumn{3}{|l|}{ Department Classification } \\
\hline Arts \& Sciences & $24.2 \%$ & $4.0 \%$ \\
\hline Architecture & $5.5 \%$ & $0.4 \%$ \\
\hline Sport and Human Dynamics & $4.4 \%$ & $17.4 \%$ \\
\hline Information Studies & $3.3 \%$ & $13.4 \%$ \\
\hline Law & $2.2 \%$ & $1.2 \%$ \\
\hline Engineering \& Computer Sciences & $17.6 \%$ & $6.9 \%$ \\
\hline Public Administration & $8.8 \%$ & $5.9 \%$ \\
\hline Communications & $6.6 \%$ & $11.2 \%$ \\
\hline Education & $4.4 \%$ & $0.8 \%$ \\
\hline Visual \& Performing Arts & $12.1 \%$ & $13.5 \%$ \\
\hline Management & $11.0 \%$ & $22.8 \%$ \\
\hline Undecided & & $1.9 \%$ \\
\hline \multicolumn{3}{|l|}{ Gender } \\
\hline Male & $56 \%$ & $56 \%$ \\
\hline Female & $43 \%$ & $44 \%$ \\
\hline Transgender & $2 \%$ & \\
\hline
\end{tabular}




\begin{tabular}{|c|c|c|c|c|}
\hline \multicolumn{5}{|c|}{$\begin{array}{c}\text { TABLE } 2 \\
\text { Library Use in the Last } 30 \text { Days (Weighted) }\end{array}$} \\
\hline \multirow[b]{2}{*}{ Activity } & \multicolumn{2}{|c|}{ FACULTY } & \multicolumn{2}{|c|}{ STUDENTS } \\
\hline & $\begin{array}{c}\text { Average } \\
\text { Frequency in } \\
\text { the Last } 30 \\
\text { Days }\end{array}$ & $\begin{array}{c}\text { \% of } \\
\text { Respondents } \\
\text { with } \\
\text { Response } \\
\text { Not Equal } \\
\text { to Zero }\end{array}$ & $\begin{array}{c}\text { Average } \\
\text { Frequency in } \\
\text { the Last } 30 \\
\text { Days }\end{array}$ & $\begin{array}{c}\% \text { of } \\
\text { Respondents } \\
\text { with } \\
\text { Response } \\
\text { Not Equal } \\
\text { to Zero }\end{array}$ \\
\hline Physical Visits & 2.50 visits & $73 \%$ & 5.07 visits & $69 \%$ \\
\hline Remote Visits & 12.31 visits & $88 \%$ & 4.64 visits & $63 \%$ \\
\hline \multicolumn{5}{|l|}{ Articles Retrieved and Read } \\
\hline $\begin{array}{l}\text { during an in-person visit from } \\
\text { a printed journal }\end{array}$ & 1.29 articles & $23 \%$ & 0.55 articles & $9 \%$ \\
\hline $\begin{array}{l}\text { during an in-person visit from } \\
\text { an online journal }\end{array}$ & 1.02 articles & $11 \%$ & 1.46 articles & $18 \%$ \\
\hline $\begin{array}{l}\text { during a remote library visit } \\
\text { from an online journal }\end{array}$ & 11.63 articles & $79 \%$ & 2.88 articles & $41 \%$ \\
\hline TOTAL & 14.94 articles & & 4.89 articles & \\
\hline $\begin{array}{l}\text { Total Articles Photocopied or } \\
\text { Printed }\end{array}$ & 3.85 articles & $62 \%$ & 1.14 articles & $25 \%$ \\
\hline $\begin{array}{l}\text { Total Articles Delivered by } \\
\text { Library to Go Campus Delivery }\end{array}$ & 0.38 articles & $5 \%$ & 0.03 articles & $2 \%$ \\
\hline \multicolumn{5}{|l|}{ Books Retrieved and Read } \\
\hline $\begin{array}{l}\text { during an in-person visit } \\
\text { (printed books) }\end{array}$ & 2.12 books & $48 \%$ & 1.12 books & $21 \%$ \\
\hline during a remote visit (e-books) & 0.48 e-books & $15 \%$ & 0.28 e-books & $10 \%$ \\
\hline TOTAL & 2.60 books & & 1.40 books & \\
\hline $\begin{array}{l}\text { Total Books Delivered by } \\
\text { Library to Go Campus Delivery }\end{array}$ & 2.07 books & $24 \%$ & 0.06 books & $1 \%$ \\
\hline \multicolumn{5}{|c|}{ Government Documents Retrieved and Read } \\
\hline during an in-person visit & 0.07 documents & $3 \%$ & 0.07 documents & $3 \%$ \\
\hline during a remote visit & 0.17 documents & $7 \%$ & 0.11 documents & $6 \%$ \\
\hline \multicolumn{5}{|l|}{ Use of Special Collections } \\
\hline in-person visits & 0.11 visits & $9 \%$ & 0.09 visits & $6 \%$ \\
\hline remote visits & 0.15 visits & $8 \%$ & 0.11 visits & $5 \%$ \\
\hline Visits to Library Commons Area & 0.82 visits & $35 \%$ & 4.66 visits & $63 \%$ \\
\hline \multicolumn{5}{|c|}{ Worked with a Professional Librarian } \\
\hline $\begin{array}{l}\text { during an in-person visit to the } \\
\text { library }\end{array}$ & 0.73 visits & $33 \%$ & 0.67 visits & $16 \%$ \\
\hline remotely online & 0.82 visits & $31 \%$ & 0.39 visits & $5 \%$ \\
\hline \multicolumn{5}{|c|}{ Attended a Library Instructional Course } \\
\hline $\begin{array}{l}\text { during an in-person visit to the } \\
\text { library }\end{array}$ & 0.04 classes & $5 \%$ & 0.03 classes & $4 \%$ \\
\hline remotely online & 0.00 classes & $1 \%$ & 0.01 classes & $2 \%$ \\
\hline
\end{tabular}




\begin{tabular}{|c|c|c|c|c|}
\hline \multicolumn{5}{|c|}{$\begin{array}{c}\text { TABLE } 2 \\
\text { Library Use in the Last } 30 \text { Days (Weighted) }\end{array}$} \\
\hline \multirow[b]{2}{*}{ Activity } & \multicolumn{2}{|c|}{ FACULTY } & \multicolumn{2}{|c|}{ STUDENTS } \\
\hline & $\begin{array}{c}\text { Average } \\
\text { Frequency in } \\
\text { the Last } 30 \\
\text { Days }\end{array}$ & $\begin{array}{c}\text { \% of } \\
\text { Respondents } \\
\text { with } \\
\text { Response } \\
\text { Not Equal } \\
\text { to Zero }\end{array}$ & $\begin{array}{c}\text { Average } \\
\text { Frequency in } \\
\text { the Last } 30 \\
\text { Days }\end{array}$ & $\begin{array}{c}\text { \% of } \\
\text { Respondents } \\
\text { with } \\
\text { Response } \\
\text { Not Equal } \\
\text { to Zero }\end{array}$ \\
\hline \multicolumn{5}{|c|}{ Used the Library for Other Purposes } \\
\hline $\begin{array}{l}\text { during an in-person visit to the } \\
\text { library }\end{array}$ & 0.35 visits & $22 \%$ & 1.82 visits & $28 \%$ \\
\hline remotely online & 1.45 visits & $14 \%$ & 0.31 visits & $7 \%$ \\
\hline \multicolumn{5}{|c|}{$\begin{array}{l}\text { Average Total Resources Used (journals, books, commons, special collections, government documents, } \\
\text { professional services, instruction) }\end{array}$} \\
\hline $\begin{array}{l}\text { during an in-person visit to the } \\
\text { library }\end{array}$ & 6.34 uses & & 10.54 uses & \\
\hline remotely online & 14.39 uses & & 4.06 uses & \\
\hline
\end{tabular}

Survey respondents were asked to identify the services they used on their most recent visit and to estimate the number of minutes they spent using each service. Faculty members spend just over an hour using the library resources in person or remotely, while students spend more than an hour using library services remotely and over two and a half hours using library facilities in person.

Table 3 displays the contingent values of faculty and students for access to library resources. It shows that faculty and students are willing to pay in time and money to gain access to library resources if they are required to acquire these resources from elsewhere. On average, faculty are willing to spend 168.73 minutes and $\$ 66.67$ to acquire the most recently used library resource they received during an in-person visit. Eighty-eight percent are willing to spend time, and 50 percent are willing to spend money, to acquire it from another source. Students are willing to spend 34.52 minutes of time and $\$ 5.31$ to acquire the most recently used library resource they received during an in-person visit. Seventy-four percent of students are willing to spend time, and 22 percent are willing to spend money, to acquire it from another source.

\section{Measuring the Value of the Academic Library}

Economists use someone's wage to determine the value of their time. ${ }^{40}$ The value of time in this study was converted to a financial equivalent by using $\$ 70$ an hour as the average value of faculty time and $\$ 10$ per hour as the average value of student time. Faculty time is calculated using the average faculty salary at Syracuse University and dividing by a 40-hour work week over a 9-month faculty contract. Student time is calculated assuming a common student hourly wage of $\$ 10$ per hour. It can be argued that both are conservative estimates of the value of time.

The money and time values in table 3 were multiplied by the annual use of resources and by the number of faculty and students to get the annual economic value of the academic library. Monthly use statistics in table 2 were adjusted by monthly variations in use estimated from turnstile and weblog statistics to get a more accurate reflection of annual use. 


\begin{tabular}{|c|c|c|c|c|}
\hline \multicolumn{5}{|c|}{ TABLE 3 } \\
\begin{tabular}{|} 
How Much Time and Effort Would it Take to Obtain the Same Resource You \\
Got from the Library from Another Source? (Weighted)
\end{tabular} \\
\hline $\begin{array}{c}\text { Resource } \\
\text { Access }\end{array}$ & Average & $\begin{array}{c}\text { \%o of Respondents } \\
\text { with Response Not } \\
\text { Equal to Zero }\end{array}$ & Average & $\begin{array}{c}\text { \% of Respondents } \\
\text { with Response Not } \\
\text { Equal to Zero }\end{array}$ \\
\hline In-Person & & & & \\
\hline Minutes & $168.73 \mathrm{~min}$ & $88 \%$ & $34.52 \mathrm{~min}$ & $74 \%$ \\
\hline Cost in Dollars & $\$ 66.67$ & $50 \%$ & $\$ 5.31$ & $22 \%$ \\
\hline Remote & & & & \\
\hline Minutes & $94.37 \mathrm{~min}$ & $96 \%$ & $32.41 \mathrm{~min}$ & $80 \%$ \\
\hline Cost in Dollars & $\$ 30.39$ & $42 \%$ & $\$ 13.14$ & $30 \%$ \\
\hline
\end{tabular}

Table 4 gives the results of these calculations. Faculty members collectively derive an annual value of $\$ 10.2$ million in time saved from in-person use of the academic library. Faculty members derive \$13.6 million annually from in-person use and \$19.0 million annually from remote use in willingness to pay in money and time.

Although students are willing to pay less in time and money for use of the academic library, there are more students than faculty at the university. In total, students derive $\$ 23.1$ million in value from in-person use and \$14.5 million from remote use of the library.

Altogether, the academic library provides $\$ 70.2$ million in value of time and money to faculty and students annually. In 2010-2011, the year of this survey, the library's annual budget was $\$ 17.0$ million, resulting in a return on investment of $4.13: 1$, or $\$ 4.13$ in economic value returned to the university for every $\$ 1.00$ spent on the library $(4.13=70.2 / 17.0)$.

This study has not estimated the environmental or social value of the academic library. This would be a more complex calculation, requiring surveys of faculty, students, and other university constituents asking about their method of transportation to the library, the frequency of printing library resources, and the value of the academic library to the institution. The environmental and social value adds to the overall calculation of the value of the library and would increase the ROI.

The return on investment of the academic library is the sum of the economic, environmental, and social value of the library divided by the annual cost. The ROI calculation for the economic value is 4.13 or $\$ 4.13$ in value provided to the university for every $\$ 1.00$ in annual cost $(=70.2 / 17.0)$.

\section{Conclusion}

This study used a contingent valuation survey to show that the annual value of the academic library at Syracuse University is $\$ 34.3$ million to faculty and $\$ 42.0$ million to students; providing $\$ 4.13$ in

\begin{tabular}{|l|c|c|}
\hline \multicolumn{3}{|c|}{ The Economic Value of the } \\
University Library \\
\hline Faculty \\
\hline Time & $\$ 10.2$ & $\$ 14.9$ \\
\hline Money & $\$ 3.4$ & $\$ 4.1$ \\
\hline Total & $\$ 13.6$ & $\$ 19.0$ \\
\hline Students & $\$ 12.0$ & $\$ 4.2$ \\
\hline Time & $\$ 11.1$ & $\$ 10.3$ \\
\hline Money & $\$ \mathbf{2 3 . 1}$ & $\$ \mathbf{1 4 . 5}$ \\
\hline Total &
\end{tabular}


value for every $\$ 1$ spent by the library. This shows a considerable return on investment of the Syracuse University library.

ROI studies do not indicate if more value will come from increasing funding. Diminishing returns may imply that increasing the library's spending may actually decrease the ROI. However, at this level of return, it is likely that every additional dollar spent will have a value of greater than a dollar and is a wise investment.

The $\$ 70.2$ million in calculated annual value of the Syracuse library underestimates its value. This study did not include the environmental or social value of the library, nor did this study measure the economic value of the library to the community or staff at the university. A great academic library will also impact student recruitment and retention, grades, and the quality of research including the funding received.

Metrics used in a valuation study should resonate with internal stakeholders - faculty and administrators. Our definition of success must come from users' definitions of library service quality. ${ }^{41}$ One further step that can be taken in this and other studies is to present the results to faculty and survey their responses to determine whether the metrics used and results found are meaningful to these stakeholders. Based on the results of such a survey, data goals of future valuation studies could be tailored and improved. In this way, researchers could know that they were addressing actual questions and concerns and have a better likelihood of achieving success as defined by the stakeholders, including presidents and provosts.

This study shows different values for faculty and students and access to physical and remote resources. Calculating costs for different users and modes of access would enable us to calculate the different ROIs, which could help library directors more efficiently allocate funding. For example, this study shows a higher ROI for digital resources than for traditional print. This could reinforce the idea that users want "ubiquity of access." 42

Additional value studies are needed for academic libraries. Replicating the methodology of one or more of the Lib-Value studies would be helpful to show the value of other university libraries and build a greater sample of data. These additional data would allow researchers to make conclusions and comparisons with greater confidence. 


\section{APPENDIX I: Survey Instrument}

\section{SECTION I: LIBRARY USE}

Survey questions ask about your in-person use of the library-including your use of print and online resources during your visit-and your remote use of the library online resources.

1. In the last 30 days, approximately how many times did you visit, in-person, any of the libraries that are part of the University Library including Bird, Math, Law, etc. Your in-person use may have been to use a journal or book, the library café, library commons, for library instruction, to use special collections, interlibrary loan, or to work with a professional librarian? (if zero, write 0)

2. In the last 30 days, approximately how many times did you visit, remotely, the University Library online resources including using the library website, searching the online databases, using online journals or book, electronic reserves, or e-mail an inquiry to a professional librarian? (if zero, write 0)

3. In the last 30 days, approximately how many articles* did you retrieve and read from the University Library:

a. during an in-person visit from a printed journal?

b. during an in-person visit from an online journal?

c. during a remote library visit from an online journal?

d. $\overline{\text { Of } a}, \mathrm{~b}$, and $\mathrm{c}$, how many did you photocopy or print?

e. $\overline{\text { Of } a}, b$, and $c$, how many did you have delivered to you by Library to Go Campus Delivery?

4. In the last 30 days, approximately how many books* did you retrieve and read from the University Library:

a. during an in-person visit (printed books)?

b. during a remote visit (e-books)?

c. Of these, how many did you have delivered to you by

*Articles can include those found in journal issues, websites, or separate copies such as preprints, reprints, and other electronic or paper copies. Reading is defined as going beyond the table of contents, title, and abstract to the body of the article.

${ }^{*}$ Books can be read in whole or in part including a single chapter, in print or virtually as a chapter or an entire book.

5. In the last 30 days, approximately how many government documents did you retrieve and read:

a. during an in-person visit?

b. during a remote visit?

6. In the last 30 days, approximately how many times did you visit, in-person, special collections*? How many times did you remotely use special collections online?

${ }^{*}$ The Special Collections Research Center (SCRC) maintains and provides access to distinguished collections of rare books, manuscripts, and other archival materials. Syracuse University students, faculty, staff, and other scholars have available to them more than 100,000 printed works and 2,000 archival collections, including important editions, manuscripts, documents, letters, diaries, drawings, photographs, and memorabilia. Syracuse University collections include the Belfer Audio Archive; works of Gutenberg, Galileo, and Newton; papers of Joyce Carol Oates, photojournalist Margaret Bourke White, painter Grace Hartigan, architects Marcel Breuer and William Lescaze, illustrator N.C. Wyeth, and sculptor Anna Hyatt Huntington, and Norman Vincent Peale among other items. 
7. In the past 30 days, approximately how many times did you use the library commons area*?

a. Describe the general purpose of your use of the library commons areas.

*Library common areas include the café and public spaces for meeting, research, using technology, or other purposes.

8. In the past 30 days, approximately how many times did you work with a professional librarian, including for reference, interlibrary loan, placing or retrieving materials from reserves, or other purposes:

a. during an in-person visit to the library?

b. remotely online?

9. In the past 30 days, approximately how many times did you attend a library instructional course:

a. during an in-person visit to the library?

b. remotely online?

10. In the past 30 days, approximately how many times did you visit the library for other purposes:

a. in-person?

b. remotely online?

Please describe what other purposes.

The following questions refer to the MOST RECENT IN-PERSON visit to the University Library. Note that this last use may not be typical, but will help us establish the range of patterns of library use.

If you do not visit the University Library in-person, check here and skip to question \#14.

11. During your most recent in-person visit to the University Library, which of the following activities did you engage in? Please estimate the time (in minutes) spent on each of these activities. Leave blank all activities you did not engage in.

\begin{tabular}{|c|c|}
\hline Activity & Time in Minutes \\
\hline \multicolumn{2}{|l|}{ Searched the library databases and/or online catalogue } \\
\hline \multicolumn{2}{|l|}{ Retrieved journal article(s) } \\
\hline in print & \\
\hline online & \\
\hline \multicolumn{2}{|l|}{ Retrieved book(s) } \\
\hline in print & \\
\hline online, e-books & \\
\hline Used government documents & \\
\hline Used the library's special collections & \\
\hline
\end{tabular}




\begin{tabular}{|l|l|}
\hline $\begin{array}{l}\text { Used the library common areas including the café, work- } \\
\text { stations, or other public spaces }\end{array}$ & \\
\hline $\begin{array}{l}\text { Worked with a professional librarian, answering a refer- } \\
\text { ence question, interlibrary loan, and the like }\end{array}$ & \\
\hline $\begin{array}{l}\text { Attended an instructional course at the library taught by } \\
\text { a member of the library staff }\end{array}$ & \\
\hline Used the library for another purpose & \\
\hline
\end{tabular}

12. Thinking back to your most recent in-person use of a University Library resource or service, please describe what you would have done had the library not provided this resource or service to you. Would you have sought the information from another source or used another resource?

a. I would have obtained the information from or sought it from another source or used another resource on campus. ____ TRUE ____ FALSE If TRUE, please specify source or resource:

b. To obtain the same resource from the source, I would expect to spend minutes of time and/or $\$$

13. When you visited the library, how did you get there?

a. I walked __ minutes to get to the campus library.

b. I drove __ minutes to get to the campus library. Parking cost me $\$$

c. I took public transportation and it took me ___ minutes to get to the campus library.

d. I took another form of transportation (please identify) it took me minutes to get to the campus library. and

The following questions refer to the MOST RECENT REMOTE VISIT to the library website, databases, or online journals. Note that this last visit may not be typical, but will help us establish the range of patterns of remote library use.

If you do not visit the university library remotely, check here and skip to question $\# 16$.

14. During your most recent remote visit of the library online from a computer outside the library, which of the following activities did you engage in? Please estimate the time (in minutes) spent on each of these activities. Leave blank all activities you did not engage in.

\begin{tabular}{|l|l|}
\hline Activity & Time in Minutes \\
\hline Searched the library databases and/or online catalogue & \\
\hline Retrieved journal article(s) online & \\
\hline Retrieved book(s) online & \\
\hline Requested Library to Go Delivery of materials & \\
\hline Used the library's government documents online & \\
\hline Used the library's special collections online & \\
\hline $\begin{array}{l}\text { Worked with a professional librarian, answering a reference question, interli- } \\
\text { brary loan, and the like }\end{array}$ & \\
\hline Used an instructional course online & \\
\hline Remotely visited the library for another purpose & \\
\hline
\end{tabular}


15. Thinking back to your most recent remote use of the library online, please describe what you would have done had the library not provided this resource or service to you. Would you have sought the information from another source or used another resource?

a. I would have obtained the information from or sought it from another source or used another resource on campus. TRUE FALSE If TRUE, please specify source or resource:

b. To obtain the same resource from the source, I would expect to spend minutes of time and/or $\$$

\section{SECTION 2: OPEN COMMENTS}

16. Please give us any comments on your use of the library in support of your teaching or research.

\section{SECTION 3: DEMOGRAPHICS (FACULTY)}

17. Please indicate your department or your professional field (such as chemistry, history, law, engineering).

18. Please specify your rank:

Professor
Associate Professor
Assistant Professor
Professor of Practice
Instructor
Teaching Assistant/Fellow
Research Faculty
Adjunct, Part-time Faculty
Staff
Other (please specify)

19. Please indicate the percentage of work time you spend during the year on the following activities: research teaching service

$\overline{100 \%}$ TOTAL

20. Please indicate your highest degree earned: Year received:

21. Gender: Male Female Transgender

22. In the past two years, approximately how many:

a. Articles in refereed scholarly journals have you published? articles

b. Non-refereed articles have you published? articles

c. Chapters in books, proceedings, and so on, have you published?

d. Entire books have you published? books

e. Total value of the external grants you received? \$ 


\section{SECTION 3: DEMOGRAPHICS (STUDENTS)}

17. What year are you in school?

freshman

_ sophomore

_ junior

_ senior or 5th-year undergraduate

_ masters/CAS

law/JD

$\mathrm{PhD}$

18. What is your major/academic department?

19. How many credit hours did you take in the Spring Semester (2011)? hours

20. Approximately what is your GPA? (indicate if unknown)

21. Gender/sex: Male___ Female___ Transgender

22. Where do you live?

on campus

within one mile of campus

more than one mile from campus

Please return the completed survey to the person giving it or your professor/teacher.

If you would like a copy of the final report when it is available, please send an e-mail to Bruce Kingma at brkingma@syr.edu.

\section{THANK YOU!}

\section{Notes}

1. Xi Shi and Sarah Levy, "A Theory-Guided Approach to Library Services Assessment," College \& Research Libraries 66 no. 3 (2005): 266-77, available online at http://crl.acrl.org/content/66/3/266.full.pdf $+\mathrm{html}$ [accessed 21 October 2013].

2. Valerie Zeithaml, A. Parasuraman, and Leonard Berry, Delivering Quality Service: Balancing Customer Perceptions and Expectations (New York: Free Press, 1990).

3. Colleen Cook, Fred Heath, Bruce Thompson, and Russel Thompson, "LibQUAL+: Service Quality Assessment in Research Libraries," IFLA Journal 27, no. 4 (2001): 264-68; Simon Nyeck, Miguel Morales, Riadh Ladhari, and Frank Pons, "10 Years of Service Quality Measurement: Reviewing the Use of the SERVQUAL Instrument," ESAN Cuadernos de Difusion 7, no. 13 (2002): 101-07, available online at www.esan.edu.pe/paginas/pdf/NyeckMorales.pdf [accessed 21 October 2013].

4. Shi and Levy, "A Theory-Guided Approach to Library Services Assessment."

5. Megan Oakleaf, Value of Academic Libraries: A Comprehensive Research Review and Report (Chicago: Association of College and Research Libraries, 2010).

6. Ibid., 41; Roswitha Poll and Philip Payne, "Impact Measures for Libraries and Information Services," Library Hi Tech 24, no. 4 (2006): 547-62.

7. William J. Patrick and Elizabeth C. Stanley, "Assessment of Research Quality," Research in Higher Education 37, no. 1 (2006): 23-41; Roger Kaufman, “Toward Determining Societal Value: Added Criteria for Research and Comprehensive Universities," The Center Reports (2001), available online at http://mup.asu.edu/kaufman1.pdf [accessed 21 October 2013]; Australian Research Council, "ERA Indicator Principles" (2008), available online at www.arc.gov.au/pdf/ERA_Indicator_Principles.pdf [accessed 21 October 2013].

8. Jonathan Gordon, Joe Ludlum, and J. Joseph Hoey, "Validating NSSE Against Student Outcomes: Are They Related?" Research in Higher Education 49, no. 1 (2008): 19-39; George D. Kuh and 
Robert M. Gonyea, "The Role of the Academic Library in Promoting Student Engagement in Learning" (presented at the ACRL Eleventh National Conference, Charlotte, North Carolina, April 10-13, 2003).

9. Mark Emmons and Wanda Martin, "Engaging Conversation: Evaluating the Contribution of Library Instruction to the Quality of Student Research," College E Research Libraries 63, no. 6 (2002): 545-60, available online at http://crl.acrl.org/content/63/6/545.full.pdf [accessed 21 October 2013]; Heidi Julien and Stuart Boon, "Assessing Instructional Outcomes in Canadian Academic Libraries," Library and Information Science Research 26 (2004).

10. Roger C. Schonfeld and Ross Housewright, "Ithaka S+R Faculty Survey 2009: Key Strategic Insights for Libraries, Publishers, and Societies," ICPSR 30001-v1 (2010): 11.

11. Roger C. Schonfeld, Kate Wulfson, and Ross Housewright, "Ithaka S+R US Faculty Survey 2012," ICPSR 34651-v1 (2013): 7.

12. Jennifer W. Arns and Susan Imholz, Worth Their Weight: An Assessment of the Evolving Field of Library Evaluation (New York: Americans for Libraries Council, 2007), 16.

13. Paul R. Portney, “The Contingent Valuation Debate: Why Economists Should Care," Journal of Economic Perspectives 8, no. 4 (1994): 3-17.

14. Richard Carson, Contingent Valuation: A Comprehensive Bibliography and History (Northampton: Edward Elgar Publishing Ltd., 2012); Peter A. Diamond and Jerry A. Hausman, "Contingent Valuation: Is Some Number Better Than No Number?" Journal of Economic Perspectives 8, no. 4 (1994): $45-64$.

15. Terrel L. Rhodes, "VALUE: Valid Assessment of Learning in Undergraduate Education," New Directions for Institutional Research (2008): 59-70.

16. Kevin J. Boyle, F. Reed Johnson, and Daniel W. McCollum, "Anchoring and Adjustment in Single-Bounded Contingent Valuation Questions," American Journal of Agricultural Economics 79 (1997); Kenneth Arrow, Robert Solow, Paul R. Portney, Edward E. Leamer, Roy Radner, and Howard Schuman, "Report of the NOAA Panel on Contingent Valuation," Federal Register 58, no. 10 (1993).

17. Scott Jaschik, "Turning Surveys into Reforms," Inside Higher Ed (Oct. 26, 2009).

18. Diamond and Hausman, "Contingent Valuation"; Robert Cameron Mitchell and Richard Thomas Carson, Using Surveys to Value Public Goods: The Contingent Valuation Method (Washington D.C.: Resources for the Future, 1989).

19. Roger Strouse, "ROI for Libraries Remains High," Access: Asia's Newspaper on Electronic Information Products and Services 63 (2007), available online at www.aardvarknet.info/access/ number63/monthnews.cfm?monthnews=06 [accessed 21 October 2013].

20. Paula Kaufman and Sarah Barbara Watstein, "Library Value (Return on Investment, ROI) and the Challenge of Placing a Value on Public Services," Reference Services Review 36, no. 3 (2008): 228.

21. Judy Luther, University Investment in the Library: What's the Return? A Case Study at the University of Illinois at Urbana-Champaign (San Diego: Elsevier Library Connect, 2008), 3-4.

22. Carol Tenopir, University Investment in the Library, Phase II: An International Study of the Library's Value to the Grants Process (San Diego: Elsevier LibraryConnect, 2010), 8.

23. Ibid., 11.

24. Ibid., 3.

25. Ibid., 6 .

26. Oakleaf, Value of Academic Libraries, 25.

27. Ibid., 93.

28. Ibid., 12-17.

29. Ibid., 32.

30. Richard P. Keeling, Andrew F. Wall, Ric Underhile, and Gwendolyn J. Dungy, Assessment Reconsidered: Institutional Effectiveness for Student Success (International Center for Student Success and Institutional Accountability, 2008).

31. Jose-Marie Griffiths and Donald King for Special Libraries Association, Special Libraries: Increasing the Information Edge (Washington D.C.: Special Libraries Association, 1988), 1.

32. Ibid., 2.

33. Jennifer Weil Arns and Susan Imholz, Worth Their Weight: An Assessment of the Evolving Field of Library Evaluation (New York: Americans for Libraries Council, 2007), 34.

34. Ibid., 32.

35. Ibid., 35 .

36. Ibid., 33.

37. Martin M. Cummings, The Economics of Research Libraries (Washington D.C.: Council on Library Resources, 1986).

38. Bruce Kingma, The Economics of Information: A Guide to Economic and Cost-Benefit Analysis for Information Professionals (Englewood, Colo.: Libraries Unlimited, Inc. 2001).

39. James Andreoni, "Impure Altruism and Donations to Public Goods: A Theory of Warm-

Glow Giving," The Economic Journal 100, no. 401 (1990): 464-77.

40. Kingma, The Economics of Information.

41. Cook, "LibQUAL+," 267-68.

42. Ibid., 266. 